\section{Godt om kognitiv miljøterapi}

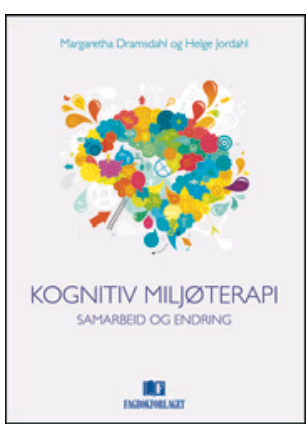

Margaretha Dramsdahl, Helge Jordahl Kognitiv miljøterapi

Samarbeid og endring. 247 s, tab, ill. Bergen

Fagbokforlaget, 2015. Pris NOK 349

ISBN 978-82-450-1775-5

Denne norske boken er skrevet av to erfarne klinikere med allsidig praksis som har erfaring fra bruk av kognitiv metode i behandling og undervisning gjennom mange år.

Boken er skrevet med tanke på ansatte i psykiatriske sengeavdelinger, rehabiliteringssentre og bofellesskap. Målgruppen er også utdanningskandidater og studenter i profesjonsutdanninger og $i$ videre- og etterutdanninger.

Det er to hoveddeler. I kapitlene 1-5 gjennomgår forfatterne det teoretiske grunnlaget for kognitiv miljøterapi, og i kapitlene 6-9 konsentrerer de seg om praktisk utøvelse av kognitiv miljøterapi.

Forfatterne begynner med et bilde av hvordan situasjonen for pasienter i psykiatriske institusjoner har endret seg. Så gjennomgår de en del forutsetninger som må være til stede for at man skal kunne lykkes med å implementere en felles modell. Det krever blant annet bevisst ledelse, god organisering og systematisk opplæring av alle ansatte.

Vi får ett glimt inn i nevrovitenskapen - forskning på sammenhengen mellom biologi og psykologi. Her er det enda mye spennende forskning som gjenstår.

Gjennomgangen av grunnprinsipper i kognitiv atferdsterapi er ryddig og oversiktlig. De legger vekt på at kognitiv miljøterapi forutsetter et tett samarbeid mellom alle ansatte i avdelingen og mellom pasient og terapeut. Metoden forutsetter brukermedvirkning, og målsettingen med tiltakene er økt egenmestring.

I den andre halvdelen beskriver forfatterne ulike verktøy, dvs. teknikker som brukes i terapien. Det er en systematisk og god gjennomgang av tiltak som egner seg for pasienten individuelt og i gruppesammenheng, og beskriver hvordan samhandling og daglige situasjoner i avdelingen kan benyttes for å hjelpe pasienten til å bli bevisst sine tanker og reaksjoner.

Boken egner seg nok best for de som har noe kunnskap om kognitiv terapi fra før. Den er nyttig både for studenter og for ledere som er opptatt av kompetanseheving i avdelingen og vurderer kognitiv miljøterapi.

Det er viktig med økt søkelys på kompetanse og kvalitet i psykiatrisk praksis og nødvendig med mer kunnskap om hvordan miljøtiltak fungerer. Her gjenstår mye arbeid, og systematiske tiltak med planlagt evaluering vil være av stor betydning.

Teksten er lettlest, med et godt språk og morsomme, små illustrasjoner. Jeg anbefaler den for alle som er interessert i og arbeider med miljøterapi som et behandlingstilbud.

\section{Oppskrifter på bedre helse}

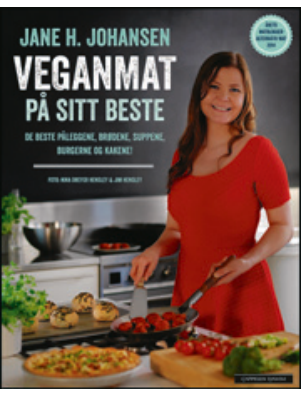

Jane H. Johansen Veganmat på sitt beste

240 s, ill. Oslo: Cappelen Damm, 2015.

Pris NOK 379

ISBN 978-82-02-47405-8
Det er per i dag bred faglig enighet om at et mer plantebasert kosthold har mange helsefordeler sammenliknet med et vanlig vestlig kosthold, og at befolkningen bør øke sitt inntak av plantekost. Samtidig kan et kosthold med lite kjøtt, egg og meieriprodukter være utfordrende for mange, fordi man ikke vet hva man kan spise isteden. Slik sett er boken et utmerket bidrag til bedre folkehelse.

Veganmat på sitt beste er en oppskriftsbok med over 100 enkle, veganske retter. Boken er inndelt etter måltider som frokost, lunsj, middag og dessert, i tillegg til festmat og bakst. Det er også en kort presentasjon av utvalgte matvarer og tips til innkjøp og tilberedning. Til slutt er det en enkel oversikt over typiske råvarer i en vegansk husholdning.

Målgruppen er både de som vil spise mindre kjøtt ut fra helse-, miljø- og dyreetiske hensyn, og de som er glad i matlaging og vil prøve noe nytt. Hensikten er å gjøre det enklere å kutte ned på forbruket av kjøtt, egg og meieriprodukter.

Boken ser innbydende, proff og solid ut. Layouten er lekker, med mange flotte, proffe bilder av rettene.

Det er spesielt positivt at rettene ikke bare baseres på grønnsaker, korn, poteter og frukt, men også på belgvekster og nøtter. Belgvekster (bønner, erter og linser) er en næringsrik, mettende og miljøvennlig erstatning for kjøtt. Belgvekster er en viktig matvaregruppe, en hjørnestein i et plantebasert kosthold, som ikke har hatt en stor plass i det moderne nordiske kostholdet. Flere oppskrifter inkluderer også nøtter, kjerner og frø, som er kilder til sunt fett og mange næringsstoffer.

Sett $i$ et helse- og næringsperspektiv ville jeg ønsket at hver av oppskriftene var deklarert med næringsinnhold, for å illustrere at en riktig sammensatt vegankost er sunn og næringsrik. Det kunne forlaget enkelt kostet på seg.

Forfatterens første kokebok ble utgitt for fem år siden. Den så beskjeden ut, men har vært et fast innslag på mitt kjøkken og bidratt til at jeg er blitt glad i veganmat. Jeg anbefaler boken spesielt fordi det ellers er utgitt svært få veganske kokebøker på norsk.

Tetyana Kalchenko

Lege, Oslo universitetssykehus

Oppgitte interessekonflikter: Anmelder er leder i foreningen Helsepersonell for plantebasert kosthold. Hun får ikke betalt for vervet og heller ingen andre økonomiske kompensasjoner. 